\title{
Oncological safety of nipple-sparing prophylactic mastectomy: A review of the literature on 3716 cases
}

\section{Sécurité oncologique de la mastectomie prophylactique conservant la plaque aréolomamelonnaire : revue de la littérature à propos de 3716 cas}

\section{T. Muller ${ }^{a}$, A. Baratte ${ }^{a}$, C. Bruant-Rodier ${ }^{a}$, F. Bodin ${ }^{a}$, C. Mathelin ${ }^{\mathrm{b}, \mathrm{c}, *}$}

\author{
a Service de chirurgie esthétique et réparatrice, CHRU, hôpitaux universitaires de Strasbourg, hôpital civil, 1, \\ place de l'Hôpital, 67091 Strasbourg cedex, France \\ ' Unité de sénologie, CHRU, hôpitaux universitaires de Strasbourg, hôpital de Hautepierre, 1, \\ avenue Molière, 67098 Strasbourg cedex 09, France \\ ' IGBMC, institut de génétique et de biologie moléculaire et cellulaire, biologie du cancer, 1 , \\ rue Laurent-Fries, 67400 Illkirch-Graffenstaden, France
}

\section{KEYWORDS \\ Nipple-sparing mastectomy; \\ Prophylactic; Oncological risk; Local recurrence}

\begin{abstract}
Summary
Introduction. - The objective of our study was to evaluate the risk of cancer after prophylactic nipple-sparing mastectomy (PNSM).

Material and methods. - The PubMed database was consulted using the following key-words: "nipple-sparing mastectomy", "prophylactic", "locoregional recurrence", "oncological risk'. Articles published between January 1995 and December 2016 were searched.

Results. - Out of the 270 articles found, 19 were included. Overall, 15 studies were retrospective, 2 prospective, 2 prospective and retrospective and 3 were multicentric. All told, they involved 3890 patients corresponding to 6786 mastectomies, among which the total number of prophylactic nipple-sparing mastectomies was 3716 . Average age of the patients was 44.4 years and average follow-up was 38.4 months (8-168 months); $29.4 \%$ of them had a BRCA 1 or 2 mutation; 85 and 15\% underwent prosthetic and autologous reconstructions, respectively. Average cancer rates exterior to and within the nipple areolar complex (NAC) were 0.2 and $0.004 \%$, respectively. The overall average rate of histological pre-malignant lesions in the nipple areolar complex was $1.5 \%$. The overall complication rate was $20.5 \%$, and necrosis rates of the nipple areolar complex and the skin were 8.1 and $7.1 \%$, respectively.
\end{abstract}

\footnotetext{
* Corresponding author. Unité de sénologie, CHRU, hôpitaux universitaires de Strasbourg, hôpital de Hautepierre, 1, avenue Molière, 67098 Strasbourg cedex 09, France.

E-mail address: carole.mathelin@chru-strasbourg.fr (C. Mathelin).
} 
Conclusion. - In prophylactic breast surgery, conservation of the nipple areolar complex does not seem to increase the risk of cancer development. However, short follow-up time and the different methodologies applied in the different studies presently preclude generalization of the technique.

(C) 2017 Elsevier Masson SAS. All rights reserved.

\section{MOTS CLÉS \\ Mastectomie prophylactique avec préservation de la PAM ; Prophylactique ; Risque oncologique ; Récidive locale}

\begin{abstract}
Résumé
Introduction. - L'objectif de cette revue était d'évaluer le risque carcinologique après mastectomie prophylactique conservant la plaque aréolo-mamelonnaire (PAM).

Matériel et méthodes. - La base de données PubMed a été utilisée avec les mots clés « nipple sparing mastectomy », « prophylactic », « locoregional recurrence », « oncological risk », de janvier 1995 à décembre 2016.

Résultats. - Sur 270 articles retrouvés, 19 ont été inclus. Quinze études étaient rétrospectives, 2 prospectives, 2 prospectives et rétrospectives et 3 multicentriques. Le nombre total de patientes incluses était de 3890, pour lesquelles 6786 mastectomies ont été réalisées dont 3716 mastectomies prophylactiques conservant la PAM. L'âge moyen des patientes était de 44,4 ans ; le suivi moyen de 38,4 mois (8-168 mois) ; $29,4 \%$ des patientes avaient une mutation délétère des gènes $B R C A 1$ ou $2 ; 85 \%$ des reconstructions étaient prothétiques et $15 \%$ autologues. Les taux moyens de développement d'un cancer à distance de la PAM et sur la PAM étaient respectivement de 0,2 et $0,004 \%$. Le taux moyen de lésions frontières ou in situ situées sous la PAM était de $1,5 \%$. Le taux de complications global était de $20,5 \%$, les taux de nécrose de la PAM et de l'étui cutané étaient respectivement de 8,1 et $7,1 \%$.

Conclusion. - Dans le cadre de la chirurgie prophylactique mammaire, la conservation de la PAM ne semble pas majorer le risque carcinologique. Cependant, le recul faible et la méthodologie des différentes études ne permettent pas de généraliser cette technique.

(C) 2017 Elsevier Masson SAS. Tous droits réservés.
\end{abstract}

\section{Introduction}

Patients presenting a high risk of developing mammary tumors connected with either a genetic mutation (BRCA1 or $B R C A 2$, for example) or family history suggesting a genetic predisposition are regularly proposed a specific treatment strategy based on clinical and imagery-based monitoring and/or prophylactic mastectomy. Over recent years, we have witnessed a trend characterized by a steady increase in the number of prophylactic mastectomies [1-3]. Rather recently, Angelina Jolie's highly publicized preventive double mastectomy furthered this phenomenon through what is now called the "Angelina Jolie effect" [4]. However, this sociological tendency runs directly counter to an increasingly pronounced breast-conserving emphasis on plastic surgery and senological procedures.

The psychological repercussions of prophylactic mastectomy vary considerably from one woman to another, in certain cases leading to unequally profound perturbations of femininity and sexuality. In fact, breast reconstruction constitutes but one among a number of variably satisfactory responses to the psychological distress experienced by those women "at high risk of breast cancer" who have decided on surgical removal of their breasts. That much said, reconstruction fails to eliminate issues of bereavement over the lost breast(s) and appropriation of the reconstructed breast(s) [5], which may nonetheless be facilitated by conservation of the skin covering and the nipple-areolar complex (NAC).

Initially reported in 1962 by Freeman [6], "subcutaneous" mastectomy was the first conservative mastectomy (CM) technique, only to give way, in the mid-1990s, to more modern methods. In the United States, a new technique, in which the skin covering is preserved but not the nippleareolar complex (NAC), skin-sparing mastectomy, was developed [7-9]. As for surgery in which the NAC is also preserved, otherwise known as nipple-sparing mastectomy (NSM), it was presented for the first time in 1999 during a congress at the University of Texas Southwestern Medical School [10]. This technique allows to avoid the secondary reconstruction of the NAC, sometimes associated with a tattoo that can fade over time, requiring iterative recolorations [11].

Generally speaking, conservative mastectomies, particularly NSM, have yielded commendable results and appreciable patient satisfaction [12-15]. However, as these techniques keep mammary tissue in place behind the NAC [16], fears have been voiced concerning NSM's oncological safety, especially insofar as this tissue could possibly be a source of loco-regional recurrence following curative Therapeutic Nipple-Sparing Mastectomy (TNSM) or of cancer occurrence subsequent to Prophylactic Nipple-Sparing Mastectomy (PNSM).

From a curative standpoint, when patient selection criteria are properly observed and when complementary treatments (radiotherapy, chemotherapy, hormonal therapy and targeted treatments) are appropriately applied, TNSM does not seem to entail any supplementary risk, as is shown in the large-scale literature review carried out by Headon et al. [17], who reported a locoregional recurrence risk of $2.38 \%$ after 38 months (7.4-156 months) of follow-up.

From a prophylactic standpoint, few studies have been dedicated to PNSM and the oncological risks it may present, even though foreknowledge of the latter is of paramount importance, given that it is rather routinely proposed, 
without complementary treatments, to women at high risk of breast cancer but who have not been suffering from mammary pathology.

The objective of this review was to evaluate the risk of cancer subsequent to PNSM through an exhaustive analysis of the recent international literature.

\section{Material and methods}

\section{Research methodology}

Research was carried out using the PubMed data base. It was consulted using the following keywords: "nipple-sparing mastectomy", " "prophylactic", "locoregional recurrence", "oncological risk". Articles published between January 1995 and December 2016 were searched. Only articles written in English or French were taken into consideration.

\section{Article inclusion and exclusion criteria}

While the abstracts of all the articles were read, only those mentioning PNSM cases (with or without associated TNSM series) involving at least 10 cases and containing analysis of cancer rates were singled out for further consideration and read in their entirety, leading to the inclusion of 19 articles; the available data on each of them were then collected (Fig. 1).

Were excluded: articles involving fewer than 10 cases, articles only mentioning TNSM series, literature reviews, commentaries and case reports.

\section{Main objective and primary endpoint}

The main objective and consequently the primary endpoint of this study was the determination of cancer rates, within and exterior to the NAC, following PNSM.

\section{Secondary objectives and secondary endpoints}

There were several secondary objectives involving evaluation of:

- cancer rates (within and exterior to the NAC) following TNSM;

- pre-malignant lesions rates in areas close to or within the NAC (through intraoperative histological analysis of the mammary tissue subjacent to the NAC) following PNSM and TNSM;

- overall complication rates;

- NAC necrosis rates;

- necrosis rates following mastectomy of the cutaneous covering.

\section{Data collection}

The data collected consisted in: the author, the review, the year of publication, the objective of the study, the type of study (prospective or retrospective), multicentricity, patient inclusion period, number of patients, total number of mastectomies, number and percentage of PNSMs and TNSMs, average age (years), follow-up (months), number and percentage of patients with a deleterious mutation of the $B R C A 1$ or $B R C A 2$ genes, cancer rate exterior to the NAC (number and \%) following PNSM and TNSM, cancer rate within the NAC (number and \%) following PNSM and TNSM, premalignant lesions in areas close to or within the NAC (number and \%) following PNSM and TNSM, overall complication rates (number and \%), NAC necrosis rates (number and \%), necrosis rates following mastectomy of the cutaneous covering (number and \%), and, finally, prosthetic and autologous reconstruction rates $(\%)$.

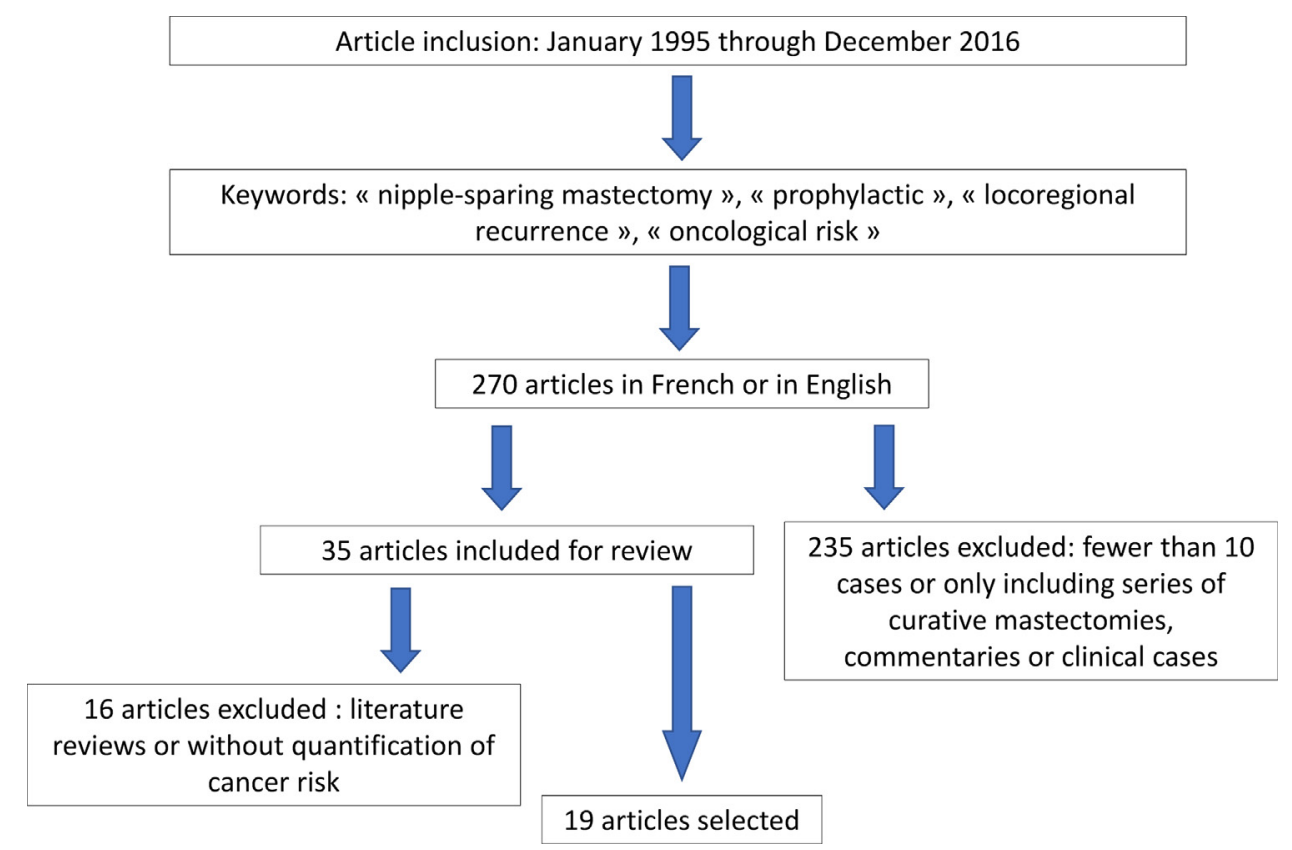

Figure 1 Flow diagram of the articles included. 


\section{Results}

All in all, 19 studies were included; their main characteristics are summarized in Table 1. Fifteen (79\%) were retrospective [18-30], 2 were prospective [31,32], and the 2 others were both retrospective and prospective $[33,34]$. Three of the studies $[33,35,36]$ were multicentric. Patient inclusion periods covered 10 years on average. The total number of patients was 3890, and all in all, they underwent 6786 mastectomies, of which 3716 were PNSMs, while 2778 were TNSMs. Taking all patients into consideration, 79\% underwent bilateral mastectomies. Average age was 44.4 years, and average follow-up was 38.4 months ( 8 to 168 months). The total number of patients with a deleterious mutation of the BRCA1 or BRCA2 genes was 617 , which came to $29.4 \%$ (in the series where the just-mentioned number was known). And, lastly, $85 \%$ of the reconstructions were prosthetic, while the remaining $15 \%$ were autologous.

Taken all the studies into consideration, Table 2 details cancer risk and pre-malignant lesions rates in areas close to or within the NAC following PNSM and TNSM. The average overall cancer rate exterior to the NAC following PNSM was $0.2 \%$, whereas the average overall cancer rate within the NAC following PNSM was $0.004 \%$. The average overall pre-malignant lesions rates in areas close to or within the NAC following PNSM was $1.5 \%$ (4.5\% following TNSM).
The different complications and their rates of occurrence are reported in Table 3 . The average overall complication rate was $20.5 \%$. The average NAC necrosis rate was $8.1 \%$, and for the cutaneous covering of the mastectomies, it was $7.1 \%$.

\section{Discussion}

One of the strengths in our review consisted in the large number of patients taken into consideration; there were 3890 of them, a figure corresponding to 6786 NSMs, among which there were 3716 PNSM procedures. To our knowledge, there has previously existed no equally large series of PNSMs. Another strength consisted in the fact that during data collection, a distinction was made between PNSM and TNSM procedures, which placed us in an ideal position to assess the cancer risks possibly stemming from PNSM.

That much said, average follow-up in our series (38.4 months) was of relatively short duration. Only four studies $[18,19,27,29]$ involved monitoring exceeding 40 months (maximum 14 years) [18]. Moreover, it was in the last-mentioned publication that the most elevated cancer rate was observed ( 7 out of the 10 different cases included in the series); this finding is likely to be associated with singularly lengthy follow-up.

Up until now, not even a single randomized study has been published. Ideally, patients having undergone prophylactic

Table 1 Main characteristics of the studies included.

\begin{tabular}{|c|c|c|c|c|c|c|c|c|c|c|}
\hline Author & Year & $\begin{array}{l}\text { Type } \\
\text { of } \\
\text { study }\end{array}$ & $\begin{array}{l}\text { Inclusion } \\
\text { period }\end{array}$ & $\begin{array}{l}\text { Patients } \\
(n)\end{array}$ & $\begin{array}{l}\text { Follow-up } \\
\text { (months) }\end{array}$ & $\begin{array}{l}\text { Average } \\
\text { age }\end{array}$ & $\begin{array}{l}\text { BRCA1/2 } \\
\text { mutation } \\
n(\%)\end{array}$ & $\begin{array}{l}\text { Mastectomies } \\
\text { (n) }\end{array}$ & $\begin{array}{l}\text { PNSM } \\
n(\%)\end{array}$ & $\begin{array}{l}\text { TNSM } \\
n(\%)\end{array}$ \\
\hline Hartmann [18] & 1999 & $\mathrm{R}$ & $1960-1993$ & 639 & 168 & 42 & ND & 1278 & $1278(100)$ & $0(0)$ \\
\hline $\begin{array}{l}\text { Yiacoumettis } \\
{[19]}\end{array}$ & 2005 & $\mathrm{R}$ & $1991-2000$ & 52 & 84 & 39.5 & $3(5.8)$ & 104 & $104(100)$ & $0(0)$ \\
\hline Sacchini [35] & 2006 & $R(M)$ & ND & 123 & 24.6 & 45 & $3(2.4)$ & 192 & $124(65)$ & $68(35)$ \\
\hline $\begin{array}{l}\text { Wijayanayagam } \\
\text { [32] }\end{array}$ & 2008 & $\mathrm{P}$ & $2001-2005$ & 43 & ND & 43.7 & $11(17)$ & 64 & $29(45)$ & $35(55)$ \\
\hline $\begin{array}{l}\text { Garcia-Etienne } \\
{[20]}\end{array}$ & 2009 & $\mathrm{R}$ & $2000-2005$ & 25 & 10.5 & 44 & ND & 42 & $34(81)$ & $8(19)$ \\
\hline Babiera [31] & 2010 & $P$ & ND & ND & 15 & ND & ND & 54 & ND & ND \\
\hline Maxwell [23] & 2011 & $\mathrm{R}$ & $2007-2009$ & 98 & 22 & ND & ND & 186 & $45(46)$ & $53(54)$ \\
\hline $\begin{array}{l}\text { Alcantara Filho } \\
\text { [21] }\end{array}$ & 2011 & $\mathrm{R}$ & $2000-2010$ & 200 & 10.4 & 44 & $36(18)$ & 353 & $196(56)$ & $157(45)$ \\
\hline Harness [22] & 2011 & $\mathrm{R}$ & 2004-2009 & 43 & 18.5 & 48.7 & $6(14)$ & 60 & $20(33)$ & $40(67)$ \\
\hline Spear [24] & 2011 & $\mathrm{R}$ & 1989-2010 & 101 & 36.5 & 43 & $23(23)$ & 162 & $113(70)$ & $49(30)$ \\
\hline $\begin{array}{l}\text { Warren Peled } \\
\text { [34] }\end{array}$ & 2012 & $P / R$ & $2001-2010$ & 428 & 28 & 46.9 & $19(4.4)$ & 657 & 245 (37) & $412(63)$ \\
\hline Camp [25] & 2014 & $\mathrm{R}$ & $2007-2012$ & ND & 8 & ND & ND & 438 & $218(50)$ & $220(50)$ \\
\hline Eisenberg [26] & 2014 & $\mathrm{R}$ & $2007-2011$ & 215 & ND & 50 & ND & 325 & 117 (36) & $208(64)$ \\
\hline Peled [27] & 2014 & $\mathrm{R}$ & $2001-2011$ & 106 & 44 & 43.7 & $53(50)$ & 212 & 104 (49) & $108(51)$ \\
\hline Yao [36] & 2015 & $\mathrm{R}(\mathrm{M})$ & 2007-2014 & 201 & 32.6 & 41 & $201(100)$ & 397 & $298(75)$ & $99(25)$ \\
\hline Manning [28] & 2015 & $\mathrm{R}$ & $2005-2013$ & 89 & 27 & 40 & $89(100)$ & 177 & $151(85)$ & $26(15)$ \\
\hline Manning [29] & 2016 & $\mathrm{R}$ & $2000-2013$ & 413 & 49 & ND & $89(22)$ & 728 & 459 (63) & 269 (37) \\
\hline Orzalesi [33] & 2016 & $\begin{array}{l}P / R \\
(M)\end{array}$ & 2009-2014 & 913 & 36 & 47 & $40(4.4)$ & 1006 & $124(12)$ & $882(88)$ \\
\hline Donovan [30] & 2016 & $\mathrm{R}$ & $2012-2015$ & 201 & ND & 47 & $44(22)$ & 351 & $57(28)$ & $144(72)$ \\
\hline Total & 1999-2016 & & $1960-2015$ & 3890 & 38.4 & 44.4 & $617(29)$ & 6786 & 3716 (57) & $2778(43)$ \\
\hline
\end{tabular}

P: prospective; R: retrospective; M: multicentric; n: number; \%: percentage; PNSM: prophylactic nipple-sparing mastectomy; TNSM: therapeutic nipple-sparing mastectomy; ND: no data. 
Table 2 Cancer risk and margins involvement rate subsequent to PNSM and TNSM in the different studies.

\begin{tabular}{|c|c|c|c|c|c|c|c|c|c|}
\hline \multirow[t]{2}{*}{ Author } & \multirow{2}{*}{$\begin{array}{l}\text { Mastectomies } \\
\text { (n) }\end{array}$} & \multirow{2}{*}{$\begin{array}{l}\text { PNSM } \\
n(\%)\end{array}$} & \multirow{2}{*}{$\begin{array}{l}\text { TNSM } \\
n(\%)\end{array}$} & \multicolumn{2}{|c|}{ PNSM } & \multirow{2}{*}{$\begin{array}{l}\text { TNSM } \\
\text { LR } \\
\text { outside } \\
\text { NAC } n(\%)\end{array}$} & \multirow{2}{*}{$\begin{array}{l}\text { PNSM } \\
\text { LR } \\
\text { within } \\
\text { NAC } n(\%)\end{array}$} & \multicolumn{2}{|c|}{ TNSM } \\
\hline & & & & $\begin{array}{l}\text { LR } \\
\text { outside } \\
\text { NAC } n(\%)\end{array}$ & $\begin{array}{l}\text { LR } \\
\text { within } \\
\text { NAC } n(\%)\end{array}$ & & & $\begin{array}{l}\text { Margin + } \\
\text { within } \\
\text { NAC, } n(\%)\end{array}$ & $\begin{array}{l}\text { Margin + } \\
\text { within } \\
\text { NAC, } n(\%)\end{array}$ \\
\hline Hartmann [18] & 1278 & $1278(100)$ & $0(0)$ & $6(0.5)$ & $1(0.1)$ & ND & ND & ND & ND \\
\hline Yiacoumettis [19] & 104 & $104(100)$ & $0(0)$ & $0(0)$ & $0(0)$ & ND & ND & ND & ND \\
\hline Sacchini [35] & 192 & $124(65)$ & $68(35)$ & $2(1.6)$ & $0(0)$ & $2(3)$ & $0(0)$ & ND & ND \\
\hline $\begin{array}{l}\text { Wijayanayagam } \\
\text { [32] }\end{array}$ & 64 & $29(45)$ & $35(55)$ & $0(0)$ & $0(0)$ & $0(0)$ & $0(0)$ & $2(6.9)$ & $0(0)$ \\
\hline $\begin{array}{l}\text { Garcia-Etienne } \\
\text { [20] }\end{array}$ & 42 & $34(81)$ & $8(19)$ & $0(0)$ & $0(0)$ & $0(0)$ & $0(0)$ & $1(2.9)$ & $0(0)$ \\
\hline Babiera [31] & 54 & ND & ND & ND & $0(0)$ & ND & $0(0)$ & ND & ND \\
\hline Maxwell [23] & 186 & $45(46)$ & $53(54)$ & $0(0)$ & $0(0)$ & $0(0)$ & $0(0)$ & $0(0)$ & $0(0)$ \\
\hline $\begin{array}{l}\text { Alcantara Filho } \\
{[21]}\end{array}$ & 353 & $196(56)$ & $157(45)$ & $0(0)$ & $0(0)$ & $0(0)$ & $0(0)$ & $0(0)$ & $11(7)$ \\
\hline Harness [22] & 60 & $20(33)$ & $40(67)$ & $0(0)$ & ND & $0(0)$ & ND & $0(0)$ & $0(0)$ \\
\hline Spear [24] & 162 & $113(70)$ & $49(30)$ & $0(0)$ & $0(0)$ & $0(0)$ & $0(0)$ & $1(0.9)$ & $4(8.2)$ \\
\hline $\begin{array}{l}\text { Warren Peled } \\
\text { [34] }\end{array}$ & 657 & 245 (37) & $412(63)$ & $0(0)$ & $0(0)$ & $8(1.9)$ & $0(0)$ & ND & ND \\
\hline Camp [25] & 438 & $218(50)$ & $220(50)$ & ND & $0(0)$ & ND & $0(0)$ & $1(0.5)$ & $21(9.5)$ \\
\hline Eisenberg [26] & 325 & $117(36)$ & $208(64)$ & ND & $0(0)$ & ND & $1(0.5)$ & $0(0)$ & $29(14)$ \\
\hline Peled [27] & 212 & 104 (49) & $108(51)$ & $0(0)$ & $0(0)$ & $1(0.9)$ & $0(0)$ & $3(2.9)$ & $2(1.9)$ \\
\hline Yao [36] & 397 & $298(75)$ & $99(25)$ & $1(0.3)$ & $0(0)$ & $3(3)$ & $0(0)$ & $0(0)$ & $3(3)$ \\
\hline Manning [28] & 177 & $151(85)$ & $26(15)$ & $0(0)$ & $0(0)$ & $0(0)$ & $0(0)$ & $6(4)$ & $2(7.7)$ \\
\hline Manning [29] & 728 & $459(63)$ & $269(37)$ & $0(0)$ & $0(0)$ & $1(0.4)$ & $0(0)$ & $4(0.9)$ & $11(4.1)$ \\
\hline Orzalesi [33] & 1006 & $124(12)$ & $882(88)$ & ND & ND & $22(2.5)$ & $5(0.6)$ & ND & ND \\
\hline Donovan [30] & 351 & $57(28)$ & $144(72)$ & ND & ND & ND & ND & $0(0)$ & $4(2.8)$ \\
\hline Total & 6786 & $3716(57)$ & $2778(43)$ & $9(0.2)$ & $1(0.004)$ & $37(0.9)$ & $6(0.1)$ & $18(1.5)$ & $87(4.5)$ \\
\hline
\end{tabular}

n: number; \%: percentage; PNSM: prophylactic nipple-sparing mastectomy; TNSM: therapeutic nipple-sparing mastectomy; LR: locoregional recurrence; NAC: nipple-areolar complex; ND: no data.

mastectomy would be randomized into two groups, one of them having had their NAC preserved, and the others having had it removed; it would then be possible to compare their respective cancer rates.

Only two of the reported series were prospective [31,32], while two others [33,34] were at once prospective and retrospective. Unfortunately, most of the articles presented descriptive as well as retrospective series, thereby detracting from their scientific weight.

More positively, in most of the articles the inclusion and exclusion criteria for patients having undergone TNSM were clearly specified. In general, patients presenting with a relatively peripheral tumor of less than $3 \mathrm{~cm}$, at more than $2 \mathrm{~cm}$ from the NAC and without axillary lymph node metastases, were included. On the other hand, the inclusion criteria pertaining to patients having undergone PNSM were not always fully detailed; as a result, it was not possible to be precisely apprised of the indications taken into consideration when deciding on PNSM performance. In 6 of the 19 articles studied, the percentage of patients having a deleterious mutation of the BRCA1 or BRCA2 genes was not known. In addition, at times it was difficult to determine whether the mutated patients included had had PNSM or TNSM.

Virtually all of the articles presented mixed series of PNSMs and TNSMs. Only two series, those of Hartmann et al. in 1999 [18] and Yiacoumettis in 2004 [19] included PNSM cases alone. Theirs were older series bringing together cases of subcutaneous mastectomy preserving the NAC complex, and they were somewhat different from surgical procedures applying more recently developed and currently employed NSM techniques. And yet, given the size ability of the above series, they were included in our study. In the article by Hartmann et al. [18], out of 639 patients having undergone 1278 PNSMs, only 7 cases of breast cancer were detected during a 168 month (14-year) follow-up period, 1 of them within the NAC and the other 6 exterior to the NAC. As for Yiacoumettis [19], out of 52 patients having undergone 104 PNSMs, during an 84 month (7-year) follow-up period no case of breast cancer was detected.

Only two series were limited to patients having deleterious mutation of the BRCA1 or BRCA2 genes. The first of them, analyzed in the article by Manning et al. [28], included 89 patients and involved 177 NSMs, of which 151 were PNSMs. In that series, no new case of breast cancer (either within or exterior to the NAC) was detected during a 27 month followup period. Secondly, the series of NSMs in the mutated patients studied by Yao et al. [36] was somewhat larger. Among 201 patients having undergone 397 NSMs of which 298 were PNSMs, only one case of breast cancer, which occurred outside the NAC, was detected during the 32.6 month followup period.

Several authors have shown interest in the residual breast tissue remaining under the NAC after mastectomy; they wished to better understand the reportedly low rates of 
Table 3 Overall complication rates, necrosis rates (NAC and skin), types of reconstruction: global perspective on the different studies.

\begin{tabular}{|c|c|c|c|c|c|c|c|}
\hline Author & $\begin{array}{l}\text { Patients } \\
(n)\end{array}$ & $\begin{array}{l}\text { Mastectomies } \\
(n)\end{array}$ & $\begin{array}{l}\text { Overall } \\
\text { complication } \\
\text { rates } \\
n(\%)\end{array}$ & $\begin{array}{l}\text { NAC } \\
\text { necrosis } \\
\text { rates } \\
n(\%)\end{array}$ & $\begin{array}{l}\text { Skin } \\
\text { necrosis } \\
\text { rates } \\
n(\%)\end{array}$ & $\begin{array}{l}\text { Reconstruction } \\
\text { by MP } \\
\text { (\%) }\end{array}$ & $\begin{array}{l}\text { Reconstruction } \\
\text { by flap } \\
\text { (\%) }\end{array}$ \\
\hline Hartmann [18] & 639 & 1278 & ND & ND & ND & ND & ND \\
\hline Yiacoumettis [19] & 52 & 104 & $4(4)$ & $1(1)$ & $2(1.9)$ & 100 & 0 \\
\hline Sacchini [35] & 123 & 192 & $43(22)$ & $22(11)$ & ND & 80.7 & 19.3 \\
\hline Wijayanayagam [32] & 43 & 64 & $27(42)$ & $3(5)$ & $11(17)$ & 46.9 & 53.1 \\
\hline Garcia-Etienne [20] & 25 & 42 & ND & $12(29)$ & ND & 100 & 0 \\
\hline Babiera [31] & ND & 54 & ND & $(7.2)$ & ND & ND & ND \\
\hline Maxwell [23] & 98 & 186 & ND & ND & ND & 98.2 & 1.8 \\
\hline Alcantara Filho [21] & 200 & 353 & $75(21)$ & ND & $69(20)$ & 99.7 & 0.3 \\
\hline Harness [22] & 43 & 60 & $12(20)$ & $9(15)$ & ND & 100 & 0 \\
\hline Spear [24] & 101 & 162 & $46(28)$ & $11(6.8)$ & $3(1.9)$ & 96.3 & 3.7 \\
\hline Warren Peled [34] & 428 & 657 & $274(42)$ & $23(3.5)$ & $78(12)$ & 85.7 & 14.3 \\
\hline Camp [25] & ND & 438 & ND & ND & ND & ND & ND \\
\hline Eisenberg [26] & 215 & 325 & ND & ND & ND & ND & ND \\
\hline Peled [27] & 106 & 212 & $39(18)$ & $3(1.4)$ & $9(4.2)$ & 84.4 & 13.6 \\
\hline Yao [36] & 201 & 397 & $33(8.3)$ & $4(1)$ & $10(2.5)$ & 5.5 & 94.5 \\
\hline Manning [28] & 89 & 177 & $37(21)$ & $6(3.4)$ & $7(4)$ & 98.9 & 1.1 \\
\hline Manning [29] & 413 & 728 & $105(14)$ & ND & $47(6.5)$ & 97 & 1.7 \\
\hline Orzalesi [33] & 913 & 1006 & $44(4.4)$ & $44(4.8)$ & $23(2.3)$ & ND & ND \\
\hline Donovan [30] & 201 & 351 & $73(21)$ & $56(16)$ & $22(6.3)$ & 93.4 & 5.1 \\
\hline Total & 3890 & 6786 & $812(20.5)$ & $194(8.1)$ & $281(7.1)$ & 85 & 15 \\
\hline
\end{tabular}

n: number: \%: percentage; NAC: nipple-areolar complex; MP: mammary prosthesis, FL: flap; ND: no data.

breast cancer subsequent to PNSM. In 2014, in a study limited to patients having had a deleterious mutation of the BRCA1 or BRCA2 genes, Baltzer et al. [37] undertook volumetric analysis by Magnetic Resonance Imaging (MRI) so as to make comparisons concerning the volume of the residual fibroglandular breast tissue remaining under the NAC after mastectomy. In their analysis, for tissue $5 \mathrm{~mm}$ thick (measured using MRI), residual breast volume at the level of the NAC was found to represent $1.3 \%$ of total breast volume. But for tissue $10 \mathrm{~mm}$ thick, it significantly increased, representing $3 \%$ of total breast volume. And so, according to the conclusions of this study, when tissue only $5 \mathrm{~mm}$ thick was removed during PNSM, subsequent residual breast volume was very small and deemed to be acceptable, a result that was not found for greater thicknesses. Rather similarly, Reynolds et al. [38] studied the NACs ( $n=62 ; 33$ prophylactic and 29 curative) having taken place in 33 patients with a deleterious mutation of the BRCA1 or BRCA2 genes. They were subsequently in a position to evaluate the percentage of NACs with terminal lobular or ductal units, as well as the percentage of NACs presenting occult malignant or "pre-malignant" lesions (atypical hyperplasia or in situ carcinoma). In this study, 15 NACs $(24 \%)$ indeed presented terminal ductal lobular units. Contrarily to 3 NACs $(10 \%)$ extracted on curative indication, none of the NACs extracted on prophylactic indications contained any occult lesion. Furthermore, according to Reynolds et al. [38], during prophylactic mastectomy in mutated patients, likelihood of NAC injury by occult lesions is exceedingly low. These observations are congruent with those of Kryvenko et al. [39], who reported $26 \%$ of NACs presenting terminal units, without any occult malignant or pre-malignant lesions appearing during prophylactic mastectomies.

Our results are complementary to those of a previous literature review published in 2015 by Van Verschuer et al. [40]. While this study brought together 24 articles, the inclusion criteria were broader, enabling analysis of different types of conservative and non-conservative (radical) prophylactic mastectomies (with or without NAC preservation) mastectomies. That said, our work is divergent from that of Van Verschuer et al. [40] insofar as these authors were aiming to compare cancer risk in conservative as opposed to non-conservative prophylactic mastectomies. All in all, 17 cases of breast cancer were observed among 5548 conservative prophylactic mastectomies, representing a rate of $0.3 \%$, as opposed to 3 cases of cancer among 496 non-conservative prophylactic mastectomies, representing a rate of $0.6 \%$. To sum up, the just-mentioned work did not determine the impact of NAC preservation on oncological risk, whereas in our study, which involved 3716 PNSMs, 9 cases $(0.2 \%)$ of breast cancer exterior to the NAC and just one case $(0.004 \%)$ within the NAC complex were detected. Our findings not only demonstrate but highlight the exceedingly low risk of cancer subsequent to PNSM.

\section{Conclusion}

The psychological repercussions of prophylactic mastectomy vary considerably from one woman to another. Breast reconstruction represents one response to the psychological distress experienced by women requesting breast ablation. Nevertheless, it fails to eliminate issues of bereavement 
over the lost breast(s) and appropriation of the reconstructed breast(s), which may nonetheless be facilitated by conservation of the skin covering and the NAC.

As concerns prophylactic mastectomies, NAC conservation does not seem to increase cancer risk either within or at some distance from the latter. Nevertheless, randomized prospective studies covering a longer period seem necessary in view of corroborating the data reported and analyzed in this paper.

\section{Disclosure of interest}

The authors declare that they have no competing interest.

\section{References}

[1] Angelos P, Bedrosian I, Euhus DM, Herrmann VM, Katz SJ, Pusic A. Contralateral prophylactic mastectomy: challenging considerations for the surgeon. Ann Surg Oncol 2015;22(10):3208-12.

[2] Tuttle TM, Habermann EB, Grund EH, Morris TJ, Virnig BA. Increasing use of contralateral prophylactic mastectomy for breast cancer patients: a trend toward more aggressive surgical treatment. J Clin Oncol 2007;25(33):5203-9.

[3] Tuttle T, Habermann E, Abraham A, Emory T, Virnig B. Contralateral prophylactic mastectomy for patients with unilateral breast cancer. Expert Rev Anticancer Ther 2007;7(8):1117-22.

[4] Evans DG, Barwell J, Eccles DM, Collins A, Izatt L, Jacobs C, et al. The Angelina Jolie effect: how high celebrity profile can have a major impact on provision of cancer related services. Breast Cancer Res 2014;16(5):442.

[5] Robiolle C, Quillet A, Dagregorio G, Huguier V. Patient-reported outcome of their breast reconstruction after mastectomy. Ann Chir Plast Esthet 2015;60(3):201-7.

[6] Freeman BS. Subcutaneous mastectomy for benign breast lesions with immediate or delayed prosthetic replacement. Plast Reconstr Surg Transplant Bull 1962;30:676-82.

[7] Toth BA, Lappert P. Modified skin incisions for mastectomy: the need for plastic surgical input in preoperative planning. Plast Reconstr Surg 1991;87(6):1048-53.

[8] Kroll SS, Marchi M. Immediate reconstruction: current status in cancer management. Tex Med 1991;87(9):67-72.

[9] Kroll SS, Ames F, Singletary SE, Schusterman MA. The oncologic risks of skin preservation at mastectomy when combined with immediate reconstruction of the breast. Surg Gynecol Obstet 1991;172(1):17-20.

[10] Laronga C, Robb G, Singletary S. Feasibility of skin-sparing mastectomy with preservation of the nipple-areola complex. Breast disease yearbook quarterly 1998;19:125-7.

[11] Riot S, Devinck F, Aljudaibi N, Duquennoy-Martinot V, Guerreschi P. Tattooing of the nipple-areola complex in breast reconstruction: technical note. Ann Chir Plast Esthet 2016;61(2):141-4.

[12] van Verschuer VM, Mureau MA, Gopie JP, Vos EL, Verhoef C, Menke-Pluijmers $M B$, et al. Patient satisfaction and nippleareola sensitivity after bilateral prophylactic mastectomy and immediate implant breast reconstruction in a high breast cancer risk population: nipple-sparing mastectomy versus skinsparing mastectomy. Ann Plast Surg 2016;77(2):145-52.

[13] Metcalfe KA, Cil TD, Semple JL, Li LD, Bagher S, Zhong T, et al. Long-term psychosocial functioning in women with bilateral prophylactic mastectomy: does preservation of the nippleareolar complex make a difference? Ann Surg Oncol 2015;22(10):3324-30.

[14] Wei CH, Scott AM, Price AN, Miller HC, Klassen AF, Jhanwar SM, et al. Psychosocial and sexual well-being following nipple-sparing mastectomy and reconstruction. Breast J 2016;22(1):10-7.
[15] Howard MA, Sisco M, Yao K, Winchester DJ, Barrera E, Warner J, et al. Patient satisfaction with nipple-sparing mastectomy: a prospective study of patient reported outcomes using the BREAST-Q. J Surg Oncol 2016;114(4):416-22.

[16] van Verschuer VM, van Deurzen CH, Westenend PJ, Rothbarth J, Verhoef C, Luiten EJ, et al. Prophylactic nipple-sparing mastectomy leaves more terminal duct lobular units in situ as compared with skin-sparing mastectomy. Am J Surg Pathol 2014;38(5):706-12.

[17] Headon HL, Kasem A, Mokbel K. The oncological safety of nipple-sparing mastectomy: a systematic review of the literature with a pooled analysis of 12,358 procedures. Arch Plast Surg 2016;43(4):328-38.

[18] Hartmann LC, Schaid DJ, Woods JE, Crotty TP, Myers JL, Arnold PG, et al. Efficacy of bilateral prophylactic mastectomy in women with a family history of breast cancer. N Engl J Med 1999;340(2):77-84.

[19] Yiacoumettis AM. Two staged breast reconstruction following prophylactic bilateral subcutaneous mastectomy. $\mathrm{Br}$ J Plast Surg 2005;58(3):299-305.

[20] Garcia-Etienne CA, Cody lii HS, 3rd, Disa JJ, Cordeiro P, Sacchini V. Nipple-sparing mastectomy: initial experience at the Memorial Sloan-Kettering Cancer Center and a comprehensive review of literature. Breast J 2009;15(4):440-9.

[21] de Alcantara Filho P, Capko D, Barry JM, Morrow M, Pusic A, Sacchini VS. Nipple-sparing mastectomy for breast cancer and risk-reducing surgery: the Memorial Sloan-Kettering Cancer Center experience. Ann Surg Oncol 2011;18(11):3117-22.

[22] Harness JK, Vetter TS, Salibian AH. Areola and nipple-areolasparing mastectomy for breast cancer treatment and risk reduction: report of an initial experience in a community hospital setting. Ann Surg Oncol 2011;18(4):917-22.

[23] Maxwell GP, Storm-Dickerson T, Whitworth P, Rubano C, Gabriel A. Advances in nipple-sparing mastectomy: oncological safety and incision selection. Aesthet Surg J 2011;31(3):310-9.

[24] Spear SL, Willey SC, Feldman ED, Cocilovo C, Sidawy M, Al-Attar A, et al. Nipple-sparing mastectomy for prophylactic and therapeutic indications. Plast Reconstr Surg 2011;128(5):1005-14.

[25] Camp MS, Coopey SB, Tang R, Colwell A, Specht M, Greenup RA, et al. Management of positive sub-areolar/nipple duct margins in nipple-sparing mastectomies. Breast J 2014;20(4):402-7.

[26] Eisenberg RE, Chan JS, Swistel AJ, Hoda SA. Pathological evaluation of nipple-sparing mastectomies with emphasis on occult nipple involvement: the Weill-Cornell experience with 325 cases. Breast J 2014;20(1):15-21.

[27] Peled AW, Irwin CS, Hwang ES, Ewing CA, Alvarado M, Esserman LJ. Total skin-sparing mastectomy in BRCA mutation carriers. Ann Surg Oncol 2014;21(1):37-41.

[28] Manning AT, Wood C, Eaton A, Stempel M, Capko D, Pusic A, et al. Nipple-sparing mastectomy in patients with BRCA1/2 mutations and variants of uncertain significance. $\mathrm{Br} \mathrm{J}$ Surg 2015;102(11):1354-9.

[29] Manning AT, Sacchini VS. Conservative mastectomies for breast cancer and risk-reducing surgery: the Memorial Sloan Kettering Cancer Center experience. Gland Surg 2016;5(1):55-62.

[30] Donovan CA, Harit AP, Chung A, Bao J, Giuliano AE, Amersi F. Oncological and surgical outcomes after nipple-sparing mastectomy: do incisions matter? Ann Surg Oncol 2016;23(10):3226-31.

[31] Babiera G, Simmons R. Nipple-areolar complex-sparing mastectomy: feasibility, patient selection, and technique. Ann Surg Oncol 2010;17(Suppl. 3):245-8.

[32] Wijayanayagam A, Kumar AS, Foster RD, Esserman LJ. Optimizing the total skin-sparing mastectomy. Arch Surg 2008;143(1):38-45 [discussion].

[33] Orzalesi L, Casella D, Santi C, Cecconi L, Murgo R, Rinaldi S, et al. Nipple sparing mastectomy: surgical and oncological outcomes from a national multicentric registry with 913 patients (1006 cases) over a six year period. Breast 2016;25:75-81. 
[34] Warren Peled A, Foster RD, Stover AC, Itakura K, Ewing CA, Alvarado $\mathrm{M}$, et al. Outcomes after total skin-sparing mastectomy and immediate reconstruction in 657 breasts. Ann Surg Oncol 2012;19(11):3402-9.

[35] Sacchini V, Pinotti JA, Barros AC, Luini A, Pluchinotta A, Pinotti $M$, et al. Nipple-sparing mastectomy for breast cancer and risk reduction: oncologic or technical problem? J Am Coll Surg 2006;203(5):704-14.

[36] Yao K, Liederbach E, Tang R, Lei L, Czechura T, Sisco M, et al. Nipple-sparing mastectomy in BRCA1/2 mutation carriers: an interim analysis and review of the literature. Ann Surg Oncol 2015;22(2):370-6.

[37] Baltzer HL, Alonzo-Proulx O, Mainprize JG, Yaffe MJ, Metcalfe KA, Narod SA, et al. MRI volumetric analysis of breast fibroglandular tissue to assess risk of the spared nipple in BRCA1 and BRCA2 mutation carriers. Ann Surg Oncol 2014;21(5):1583-8.

[38] Reynolds C, Davidson JA, Lindor NM, Glazebrook KN, Jakub JW, Degnim AC, et al. Prophylactic and therapeutic mastectomy in BRCA mutation carriers: can the nipple be preserved? Ann Surg Oncol 2011;18(11):3102-9.

[39] Kryvenko ON, Yoon JY, Chitale DA, Lee MW. Prevalence of terminal duct lobular units and frequency of neoplastic involvement of the nipple in mastectomy. Arch Pathol Lab Med 2013;137(7):955-60.

[40] van Verschuer VM, Maijers MC, van Deurzen CH, Koppert LB. Oncological safety of prophylactic breast surgery: skin-sparing and nipple-sparing versus total mastectomy. Gland Surg 2015;4(6):467-75. 